\title{
Effect of Marketing Mix on Consumer Purchase Decisions to Buy Cavendish Banana at Modern Markets in Semarang
}

Tutik Istiqomatin a,1,*, Agus Setiadi b,2, Titik Ekowati b,3

$a, b, c$ Department of Agribusiness, Faculty of Animal and Agricultural Sciences, Universitas Diponegoro, Jl. Prof. Soedarto, SH. Tembalang, Semarang, Central Java

Istiqomahws78@gmail.com, agus_setiadi2006@yahoo.co.id, tiekowati@yahoo.co.id

${ }^{*}$ Corresponding author

\begin{tabular}{|c|c|}
\hline ARTICLE INFO & ABSTRACT \\
\hline $\begin{array}{l}\text { Article history } \\
\text { Received April 10, } 2021 \\
\text { Revised June 03, } 2021 \\
\text { Accepted June 07, } 2021 \\
\text { Published October 29, } 2021 \\
\text { Keywords } \\
\text { Cavendish banana } \\
\text { Marketing mix } \\
\text { Modern market } \\
\text { Purchase decision }\end{array}$ & $\begin{array}{l}\text { This study aims at identifying marketing mix of purchase decisions to buy Cavendish } \\
\text { banana and analyzing the effect of marketing mix on purchase decisions to buy } \\
\text { Cavendish banana at modern market in Semarang. This research was conducted at } \\
\text { modern market in Semarang, namely Gelael Supermarket, Ada Swalayan, Superindo and } \\
\text { Giant. Survey was employed as research method in this study. } 100 \text { respondents were } \\
\text { taken for research sampling. The independent variables used were products, prices, } \\
\text { places, and promotions, while the dependent variable was decisions. Descriptive analysis } \\
\text { having been conducted shows that the variables of product have an average of } 4.14 \text {; a } \\
\text { variable of price is } 3.65 \text {; a variable of place is } 4.32 \text {, a variable of promotion is } 3.26 \text {; and a } \\
\text { variable of purchase decision is } 3.85 \text {. Statistical analysis having been carried out shows } \\
\text { that the f-test of product, price, place and promotion variables simultaneously affect the } \\
\text { consumer purchase decision to buy Cavendish bananas with an } f \text {-count value of } 26.378 \text {. } \\
\text { Besides, the results of the } t \text {-test of product, price and promotion variables partially affect } \\
\text { the consumer purchase decision to buy Cavendish bananas with } t \text {-count value of } 1.984 \text {. } \\
\text { Moreover, the place variable does not partially affect the consumer purchase decision to } \\
\text { buy at Modern Market in Semarang. } \\
\text { This is an open access article under the CC-BY-SA license }\end{array}$ \\
\hline
\end{tabular}

\section{INTRODUCTION}

Bananas are one of the commodities easily cultivated and developed in Indonesia. According to Badan Pusat Statistika (2018), province of Central Java becomes the fourth most significant producer in Indonesia after Province of East Java, Lampung and West Java in which the province be able to produce 7.26 million tons of annual fruit crop, bananas, in 2018. Bananas offer much nutritional content, among others: fat, magnesium, potassium, phosphorus, iron, calcium and vitamins (Suyanti \& Supriyadi, 2008). Bananas also have a relatively cheap price, and they are easy to obtain. Therefore, bananas are in great demand by the public.

Bananas are is the most commonly found fruit. There are several types of bananas in Indonesia, such as baba banana, cavendish banana, cotton banana, latundan banana, ambon banana, plantain, badak banana and nagka banana, all of which have their own characteristics. These types of bananas can be consumed directly or processed first into processed products. One type of bananas that can be consumed directly is 
Cavendish banana. Cavendish bananas are bananas cultivated through tissue culture. Cavendish bananas have a clean yellow peel, soft flesh and not too sweet taste. Cavendish bananas are more commonly known as Ambon bananas. It is due to the taste and shape of Cavendish bananas which are almost the same as Ambon bananas (Shintia, 2019). The advantages of Cavendish bananas frequently cause consumers thinking that Cavendish bananas are imported bananas even though Cavendish bananas have been cultivated locally and produced by several companies with various brands like Sunpride and Frui Petite.

The increasing number of companies cultivating or producing Cavendish bananas with various brands has resulted in competition in marketing activities. Marketing is an activity in delivering products or services to consumers by a company or marketer (Shinta, 2011). Marketing activities aim at maintaining production activities, gaining profits and developing its production activities. It is also important for producers to know the wish and needs of the target market, namely what factors influence consumers in making purchases (Indriyanti et al., 2019). This goal can be achieved if marketing activities are well designed and planned, so that the company or marketer can compete with other companies (Pertiwi et al., 2016).

The design and planning of marketing activities can be done by using a marketing strategy in the form of a marketing mix. According to Shintia (2019), marketing mix can be used as a tactical plan to meet the needs of the market to join the competition. The marketing mix consists of external and internal factors. External factors are factors coming from outside the company such as government, competitors, environment and technology, while internal factors consist of several variables, namely price, product, promotion and place or distribution channel (Pertiwi et al., 2016). Factors that can be cultivated by producers or marketers are internal factors consisting of price, product, promotion and place or distribution channel. These components are combined as a marketing tool to increase consumer interest in making a purchase (Octaviani et al., 2017). marketing mix affects purchase decisions. It is because if consumers decide to make a purchase, the purpose of doing a marketing mix strategy will be achieved, namely increasing sales volume and increasing profits (Suardika et al., 2014).

There are several studies on purchase decisions toward banana. First, research conducted by Rumapea et al. (2021), in their research, they show that the factors considered by consumers in deciding to buy bananas are taste, peel color, size and number of banana per comb, while in buying bananas, consumers have their preferences, namely banana size which is medium, bananas with a greenish yellow peel color, bananas which taste slightly sweet and a great number of banana per comb. Second is research by Shintia (2019) showing that in making the decision to purchase Cavendish bananas, consumers are based on their habits, and it also because of content contained in Cavendish bananas. Consumers also obtain information from family members and promotions carried out in making the decision. Consumers are satisfied buying Cavendish bananas because the place of to buy this banana is complete. The novelty of this study is to analyze several factors affecting the decision to purchase bananas in previous studies, which are integrated into the marketing mix, namely product, price, place and promotion. This study aims at identifying and analyzing the effect of the marketing mix on the decision to purchase Cavendish bananas at Modern Market in Semarang. This research is expected to provide an overview of the decision to purchase Cavendish bananas, so that it can be taken into consideration in the preparation of the marketing strategy of Cavendish banana.

\section{METHOD}

The research was conducted from November 2020 to January 2021 at modern markets in Semarang, namely Gelael Supermarket, Ada Supermarket, Superindo and Giant. Determination of the research site is conducted by using the purposive method. In this method, the site is determined based on certain criteria and considerations. The consideration of taking this site is based on the fact that these modern markets are markets in Semarang selling Cavendish bananas, and they are modern markets having been around for a long time and already have several branches in Semarang. The research method employed is survey. Survey is a research method carried out by taking samples from the population that will be used in research (Yusuf, 2017). The method of determining the sample uses a quota of 100 respondents, while for sampling using accidental sampling. According to Darmawan(2017), accidental sampling is a sampling technique with an element of accident or coincidence. Respondents involved are consumers purchasing and consuming Cavendish bananas sold in modern markets in Semarang, namely Gelael Supermarket, Ada Swalayan, Superindo and Giant. The independent variables involved are price, product, promotion and place, while the dependent variable is purchase decisions. 
In this study, the data analyzed are conducted on secondary and primary data. Primary data were collected by utilizing a questionnaire. Meanwhile, secondary data were collected by observation and literature study. Descriptive and quantitative analysis are employed for data processing. Descriptive analysis is used to answer the first objective, namely identifying the marketing mix (price, product, promotion and place) and decisions to purchase. Descriptive analysis is a way of analyzing the data used to provide an overview of the data collected (Sugiyono, 2015). Quantitative analysis is used to answer the second objective, namely to analyze the effect of the marketing mix on decisions to purchase. Quantitative analysis is a way of analyzing data using numbers, and the way to calculate those numbers is using statistical application like SPSS (Darmawan, 2013).

Validity test is a test employed to measure the validity or accuracy of a data or instrument in research (Murod et al., 2018). The validity test can be seen through the value of Corrected Item-Total Correlation. If the value of $r_{\text {count }}>r_{\text {table, }}$, the data can be said to be valid (Padmi et al., 2017).

Reliability test is a test utilized to test an instrument that is quite reliable in collecting research data so that the measurement results are relatively the same even though the measurement of variables is repeated (Murod et al., 2018). Hanifaradiz dan Satrio (2016) states that if the value of Cronbach alpha in the reliability test is $>0.6$, the instrument is reliable. Therefore, if it is repeated, the same data will be obtained even though it is carried out at different times.

Normality test is a test aiming at determining the distribution of a data used in whether the regression model is normal or not (Murod et al., 2018). A data is said to be normal if the data spreads along a diagonal line that is in the direction of the line of $45^{\circ}$ (Sugiarto et al., 2017). The normality test is carried out using the KolmogorovSmirnov test. The condition is that if the significant value is $5 \%$ or 0.05 , the data is normal (Annisa et al., 2017).

The multicollinearity test aims at finding out whether the independent variables of this study have a relationship or not. If the independent variables do not have a relationship, the variable is eligible to be used as an independent variable (Rakasyifa \& Mukti, 2020). The multicollinearity test can be determined by using the tolerance value and the variance inflation factor (VIF). The data is said to have no multicollinearity if the tolerance value is $>0.10$, and the value of VIF is $<10$ (Sugiarto et al., 2017).

The autocorrelation test aims at determining the occurrence of a correlation between the current confounding variable and the previous confounding variable (Manik \& Rianti, 2019). Autocorrelation test can be found through the Durbin-Watson test. There are three criteria in the autocorrelation test. First, if DW lies between $\mathrm{dL}$ and $\mathrm{dU}$ or between $(4-\mathrm{dU})$ and $(4-\mathrm{dL})$, it cannot be concluded with certainty; second, if $\mathrm{DW}$ lies between $\mathrm{dU}$ and $(4-\mathrm{dU})$, there is no autocorrelation; and third, if $\mathrm{dW}<\mathrm{dL}$ or $\mathrm{dW}>(4-\mathrm{dL})$, autocorrelation occurs (Zamroni, 2016).

The heteroscedasticity test aims at determining the variance of the residuals between observations. If the variance of the residuals from one observation to another observation is not the same, the observation has heteroscedasticity (Murod et al., 2018). The heteroscedasticity test can be implemented through the scatterplot graph. If the points on the scatterplots do not spread and form a pattern or are above or below the value of 0 on the $Y$ axis, the data does not experience heteroscedasticity (Sugiarto et al., 2017).

Multiple linear regression test aims at measuring the effect between two variables and showing the direction of the relationship of the independent and the dependent variable (Sugiarto et al., 2017). The multiple linear regression equation in this study is as follow:

Information:

$$
\mathrm{Y}=\alpha+\beta_{1} \mathrm{X}_{1}+\beta_{2} \mathrm{X}_{2}+\beta_{3} \mathrm{X}_{3}+\beta_{4} \mathrm{X}_{4}+\mathrm{e}
$$

$\mathrm{Y} \quad=$ Purchase decision (score)

a $\quad=$ Constanta

$X_{1}=$ Product

$X_{2} \quad=$ Price

$\mathrm{X}_{3} \quad=$ Place

$X_{4} \quad=$ Promotion

$\beta 0-\beta 4=$ coefficient of every variable

$\mathrm{e} \quad=$ error

\section{$F$-test}

F-test is a test aiming at proving the effect of the marketing mix (price, product, promotion and place) on the decision to purchase Cavendish bananas at Modern Market of Semarang simultaneously. 
$\mathrm{H}_{0}=>$ Price, product, promotion and place factors simultaneously have no effect on the decision to purchase Cavendish bananas at Modern Market in Semarang.

$\mathrm{H}_{1}=>$ Price, product, promotion and place factors simultaneously affect the decision to purchase Cavendish bananas at Modern Market in Semarang.

Acceptance Rules according to Ghozali (2018) :

$\mathrm{H}_{0}$ is rejected, and $\mathrm{H}_{1}$ is accepted if the significance value is 0.05 . Therefore, the independent variables (price, product, promotion and place factors) have a significant effect on the dependent variable (purchase decisions). $\mathrm{H}_{0}$ is accepted, and $\mathrm{H}_{1}$ is rejected if the significance value is $>0.05$. Therefore, the independent variables (price, product, promotion and place factors) have no significant effect on the dependent variable (purchase decisions).

T-test is a test aiming at partially proving the effect of the marketing mix (price, product, promotion and place) on the decision to purchase Cavendish bananas at Modern Market of Semarang.

$\mathrm{H}_{0}=>$ Price, product, promotion and place factors partially have no effect on the decision to purchase Cavendish bananas at Modern Market in Semarang.

$\mathrm{H}_{1}=>$ Price, product, promotion and place factors partially affect the decision to purchase Cavendish bananas at Modern Market of Semarang.

Acceptance Rules according to Ghozali (2018) :

$\mathrm{H}_{0}$ is rejected, and $\mathrm{H}_{1}$ is accepted if the significance value is 0.05 . Therefore, the independent variables (price, product, promotion and place factors) have a significant effect on the dependent variable (purchase decisions). $\mathrm{H}_{0}$ is accepted, and $\mathrm{H}_{1}$ is rejected if the significance value is $>0.05$. Therefore, the independent variables (price, product, promotion and place factors) have no significant effect on the dependent variable (purchase decisions).

\section{RESULTS AND DISCUSSION}

\section{General overview of respondents}

Table 1 shows that the number of respondents is 18 men and 82 women. It means that consumers consuming and purchasing Cavendish bananas in modern market of Semarang are dominated by women. It is in line with Eliza et al. (2011) stating that women perform an significant role in accommodating the daily needs of a household, including in making decisions to purchase fruit including bananas. Women tend to gain weight more easily, either from hormonal disturbances or from a lack of physical activity. Therefore, consuming Cavendish bananas is good for women. According to Setianingsih et al. (2017), Cavendish bananas contain crude fiber which is good for the digestive tract, and it can be consumed in large quantities because it contains relatively little fat.

Table 1. General overview of respondents

\begin{tabular}{|c|c|c|c|}
\hline No. & General overview of respondents & $\begin{array}{l}\text { Total of Respondent } \\
\text { (person) }\end{array}$ & Percentage (\%) \\
\hline \multirow[t]{3}{*}{1} & Gender & & \\
\hline & Man & 18 & 18 \\
\hline & Woman & 82 & 82 \\
\hline \multirow[t]{6}{*}{2} & Age & & \\
\hline & $\leq 20$ y.o. & 16 & 16 \\
\hline & $21-30$ y.o. & 66 & 66 \\
\hline & $31-40$ y.o. & 3 & 3 \\
\hline & $41-50$ y.o. & 11 & 11 \\
\hline & $51-60$ y.o. & 4 & 4 \\
\hline \multirow[t]{6}{*}{3} & Last education & & \\
\hline & Elementary School & 3 & 3 \\
\hline & Junior High School & 5 & 5 \\
\hline & Senior High School & 52 & 52 \\
\hline & Diploma III & 9 & 9 \\
\hline & Bachelor (S1) & 31 & 31 \\
\hline \multirow[t]{5}{*}{4} & Profession & & \\
\hline & Student & 48 & 48 \\
\hline & Housewife & 12 & 12 \\
\hline & Entrepreneur & 24 & 24 \\
\hline & Health workers & 3 & 3 \\
\hline
\end{tabular}




\begin{tabular}{lcc}
\hline No. General overview of respondents & $\begin{array}{c}\text { Total of Respondent } \\
\text { (person) }\end{array}$ & Percentage (\%) \\
\hline Teacher & 2 & 2 \\
Farmer & 2 & 2 \\
Civil servant & 1 & 1 \\
Private sector employee & 1 & 1 \\
Fresh graduate & 7 & 7 \\
\hline
\end{tabular}

Source: Primary Data Analysis, 2021

The most consumers of Cavendish bananas at modern market in Semarang are in the age range of 21-30 $y .0$ where this age is an active age with the peak of the body's metabolic rate. Therefore, sufficient nutritional content can help the body's metabolic processes and reduce the risk of diseases that may arise. It is in line with the opinion of Setianingsih et al. (2017) stating that protein and crude fiber contained in Cavendish bananas play a role in the growth process and the digestive tract so that they can be a source of protein and fiber. It is supported by Amanda(2011)stating that the potassium content in Cavendish bananas is about $476 \mathrm{mg}$ which is useful for lowering blood pressure. Most of the respondents' last education are senior high school. It means that consumers purchasing Cavendish bananas at the modern market in Semarang are educated. The education that has been taken provides them insight and awareness of the importance of the nutritional content, like minerals, carbohydrates, vitamins, protein, fat and water, to be consumed. Hence, they are aware that consuming bananas can fulfill some of the nutrients required by their body. Setianingsih et al. (2017) state that bananas contain various nutritional content like minerals, carbohydrates and vitamins, while the protein and crude fiber content in Cavendish bananas is relatively higher, and the fat content is relatively lower.

The respondents in this study have a variety of jobs and some are still studying. It shows that consumers purchasing and consuming Cavendish bananas sold in the modern market of Semarang are respondents who already have jobs, so they can afford to purchase. It is in line with Amilia (2017) stating that personal factors that can affect the purchasing decisions are age, cycle and lifestyle, profession, personality and economic circumstances. Respondents who are still studying, like students and university students, also purchase and consume Cavendish bananas because they are still in the active age category with the peak of the body's metabolic rate so that sufficient nutritional content can help their body's metabolic processes. Setianingsih et al. (2017) state that the protein and crude fiber contained in Cavendish bananas play a role in the growth process and the digestive tract so that they can be a source of protein and fiber.

\section{Instrument feasibility test}

The results of the validity test showed that the variables of price, product, promotion and place had a value of $r_{\text {count }}>r_{\text {table }}$, and all of them had a significance value of $<0.05$ so that the instrument used was valid. It means that the measuring instrument is able to measure what is measured in this study. It is in line with the opinion of Prasastiningtyas \& Djawoto (2016) stating that the provisions in the validity test in a study in which if the $\mathrm{r}_{\text {result }}$ or $r_{\text {count }}$ is greater than $r_{\text {table }}$ with a significance value of less than $5 \%$, the instrument is already valid.

Table 2. Result of reliability test

\begin{tabular}{|c|c|c|}
\hline Variable & Cronbach's Alpha & Information \\
\hline Product & 0.723 & Reliable \\
\hline Price & 0.879 & Reliable \\
\hline Place & 0.867 & Reliable \\
\hline Promotion & 0.950 & Reliable \\
\hline Purchasing Decision & 0.891 & Reliable \\
\hline
\end{tabular}

Source: Primary Data Analysis, 2021

Based on Table 2, it can be seen that the variables of price, product, promotion, place and purchase decisions have a Cronbach's alpha value of more than 0.6. Hence, it can be said that the instrument used is reliable. It is in line with Hanifaradiz \& Satrio (2016) stating that in the reliability test, if the value of Cronbach alpha $>0.6$, the instrument can be said to be reliable. Therefore, if it is repeated, it will produce the same data even though it is done at different times.

\section{Descriptive analysis}

The data analyzed in descriptive analysis are the variables of price, product, promotion, place and purchase decisions. The distribution of respondents' answers is presented in the following table: 
Table 3. Distribution of respondents' answers on product variables

\begin{tabular}{|c|c|c|c|c|c|c|c|}
\hline \multirow[b]{2}{*}{ No } & \multirow[b]{2}{*}{ Statement } & \multicolumn{5}{|c|}{ Respondent's Answer (\%) } & \multirow[b]{2}{*}{$\begin{array}{c}\text { Mea } \\
\mathrm{n}\end{array}$} \\
\hline & & $\begin{array}{l}\text { Strongly } \\
\text { disagree }\end{array}$ & Disagree & $\begin{array}{c}\text { Neither } \\
\text { agree } \\
\text { nor } \\
\text { disagree }\end{array}$ & Agree & $\begin{array}{l}\text { Strongly } \\
\text { agree }\end{array}$ & \\
\hline 1 & $\begin{array}{l}\text { Attractive Cavendish banana peel } \\
\text { color }\end{array}$ & 0 & 0 & 4 & 54 & 42 & 4.38 \\
\hline 2 & $\begin{array}{l}\text { Sweet and flavorful taste of } \\
\text { Cavendish banana }\end{array}$ & 0 & 2 & 11 & 64 & 23 & 4.08 \\
\hline 3 & $\begin{array}{l}\text { a great number of bananas per } \\
\text { comb }\end{array}$ & 0 & 2 & 26 & 45 & 27 & 3.97 \\
\hline & & $X_{1}$ & & & & & 4.14 \\
\hline
\end{tabular}

Source: Primary Data Analysis, 2021

Table 3 shows that the appearance of Cavendish bananas in terms of peel color is good and attracts the attention of consumers to purchase. It is as opinion of Shintia (2019) stating that Cavendish bananas have a clean yellow peel, soft flesh and not too sweet taste, so it is often considered that Cavendish bananas are imported bananas even though Cavendish bananas have been cultivated locally. The taste and aroma of Cavendish bananas are in accordance with the wishes of most respondents although there are still some that are not in accordance with the wishes of some respondents. Most consumers prefer Cavendish bananas in large quantities to Cavendish bananas in small quantities. It is in line with Rumapea et al. (2021) stating that the most often purchased bananas at the research site were baba banana, latundan banana, ambon banana, and cavendish banana. Moreover, consumers prefer bananas with a large number of bananas per comb to bananas with fewer number of bananas per comb.

Table 4. Distribution of respondents' answers on variables of price

\begin{tabular}{llllcccccc}
\hline & & \multicolumn{5}{c}{ Respondent's Answer (\%) } \\
\cline { 3 - 7 } No. Statement & $\begin{array}{c}\text { Strongly } \\
\text { disagree }\end{array}$ & Disagree $\begin{array}{c}\text { Neither } \\
\text { agree } \\
\text { nor } \\
\text { disagree }\end{array}$ & Agree & $\begin{array}{c}\text { Strongly } \\
\text { agree }\end{array}$ & Mean \\
\hline 1 & $\begin{array}{l}\text { The price of Cavendish bananas is } \\
\text { affordable }\end{array}$ & 2 & 5 & 35 & 46 & 12 & 3.61 \\
2 & $\begin{array}{l}\text { Cavendish banana price is } \\
\text { according to its quality }\end{array}$ & 0 & 2 & 15 & 61 & 22 & 4.03 \\
3 & $\begin{array}{l}\text { There is a discount applied on } \\
\text { Cavendish bananas }\end{array}$ & 7 & 10 & 41 & 28 & 14 & 3.32 \\
\hline
\end{tabular}

Source: Primary Data Analysis, 2021

Table 4 shows that the price of Cavendish bananas is still affordable for most consumers, while the others do not agree with that. It may be due to the different profession possessed by the respondents, resulting in different incomes. It is in line with the opinion from Sungkawa et al. (2015) stating that consumers prefer to purchase bananas at prices that match their income. Consumers are satisfied with the quality obtained when compared to the price given considering the Cavendish banana cultivation process is carried out with standard that has quality. Jamaluddin et al. (2019) argues that the cultivation and care of Cavendish bananas is carried out specifically starting from leaf pruning, injections to the banana blossom, bulking, flower removal, fruit disposal, fruit barrier removal, installation of fruit screens, fertilization, handling plant diseases to the harvesting process. The discount applied to price of Cavendish banana products is still rare, so some consumers never get the discount. Therefore, discounts to the products must often be done so that consumers are interested in purchase the product. According to Sundalangi et al. (2014), Discounts given by a company to a product can increase the interest to purchase the product. 
Table 5. Distribution of respondents' answers on variables of place

\begin{tabular}{|c|c|c|c|c|c|c|c|}
\hline \multirow[b]{2}{*}{ No } & \multirow[b]{2}{*}{ Statement } & \multicolumn{5}{|c|}{ Respondent's Answer (\%) } & \multirow[b]{2}{*}{$\begin{array}{c}\text { Mea } \\
\mathrm{n}\end{array}$} \\
\hline & & $\begin{array}{l}\text { Strongly } \\
\text { disagree }\end{array}$ & Disagree & $\begin{array}{c}\text { Neither } \\
\text { agree } \\
\text { nor } \\
\text { disagree }\end{array}$ & Agree & $\begin{array}{l}\text { Strongly } \\
\text { agree }\end{array}$ & \\
\hline 1 & Sale point is easy to reach & 1 & 1 & 5 & 44 & 49 & 4.39 \\
\hline 2 & $\begin{array}{l}\text { Cleanliness of the sale point is } \\
\text { guaranteed }\end{array}$ & 0 & 0 & 7 & 38 & 55 & 4.48 \\
\hline 3 & $\begin{array}{l}\text { The availability of Cavendish } \\
\text { banana products is guaranteed }\end{array}$ & 0 & 0 & 13 & 64 & 23 & 4.10 \\
\hline 4 & $\begin{array}{l}\text { Cavendish banana products are } \\
\text { placed in an easy-to-find place, } \\
\text { and they are neatly arranged }\end{array}$ & 0 & 1 & 5 & 57 & 37 & 4.30 \\
\hline
\end{tabular}

Source: Primary Data Analysis, 2021

Table 5 shows that the selected place as a sale point is strategic because most respondents feel that the place is easy to reach so that consumers can easily find the place even though there are still some respondents who do not agree. It is in accordance with the opinion of Enggal et al. (2019) stating that road access to the sale point, a clean and comfortable place affects purchasing decisions. The place of sale is considered clean so that consumers are more comfortable in making purchases. It is similar to Sesunan et al. (2015) stating that the quality of service, sales promotion and cleanliness of the place significantly affect purchase decisions.

Cavendish bananas sold at the Modern Market in Semarang are readily available so that consumers do not feel disappointed if the desired product is not available. According to Apriando et al. (2019), in making purchase decisions, one of the important things is to ensure the availability of a product because if the availability of the product is not guaranteed, it can reduce consumer's interest in making purchase. Most consumers consider that the arrangement of Cavendish banana products is good because they are neatly arranged, and consumers are easier to find so that it will be easier to make purchase decisions even though there are still respondents who disagree. It is in line with Winawan \& Yasa (2014) stating that the arrangement of a product has an effect on purchase decisions, where the better the product structuring strategy, the more opportunities in making purchase decisions will also increase.

Table 6. Distribution of respondents' answers on variables of promotion

\begin{tabular}{|c|c|c|c|c|c|c|c|}
\hline \multirow[b]{2}{*}{ No. } & \multirow[b]{2}{*}{ Statement } & \multicolumn{5}{|c|}{ Respondent's Answer (\%) } & \multirow[b]{2}{*}{ Mean } \\
\hline & & $\begin{array}{l}\text { Strongly } \\
\text { disagree }\end{array}$ & Disagree & $\begin{array}{l}\text { Neither } \\
\text { agree } \\
\text { nor } \\
\text { disagree }\end{array}$ & Agree & $\begin{array}{c}\text { Strongly } \\
\text { agree }\end{array}$ & \\
\hline 1 & $\begin{array}{l}\text { Promotions carried out through } \\
\text { events/exhibitions cause the } \\
\text { consumers are interested in } \\
\text { making purchase }\end{array}$ & 10 & 7 & 43 & 27 & 13 & 3.26 \\
\hline 2 & $\begin{array}{l}\text { Promotions carried out through } \\
\text { advertisement cause the } \\
\text { consumers are interested in } \\
\text { making purchase }\end{array}$ & 11 & 9 & 38 & 33 & 9 & 3.20 \\
\hline 3 & $\begin{array}{l}\text { Promotions carried out through } \\
\text { social media cause the consumers } \\
\text { are interested in making purchase }\end{array}$ & 11 & 6 & 35 & 37 & 11 & 3.31 \\
\hline & & $X_{4}$ & & & & & 3.26 \\
\hline
\end{tabular}

Source: Primary Data Analysis, 2021

Table 6 shows that promotions carried out through events/exhibitions and advertisements are less than optimal, while promotions through social media are maximal enough. Therefore, they need to increase the promotion to attract consumers to purchase Cavendish bananas. It is as the opinion from Weenas (2013) stating 
that to attract consumers' interest to purchase, producers need to carry out promotions through brochures, web, television, print media or exhibitions.

Table 7. Distribution of respondents' answers on variables of purchase decision

\begin{tabular}{|c|c|c|c|c|c|c|c|}
\hline \multirow[b]{2}{*}{ No. } & \multirow[b]{2}{*}{ Statement } & \multicolumn{5}{|c|}{ Respondent's Answer (\%) } & \multirow[b]{2}{*}{ Mean } \\
\hline & & $\begin{array}{l}\text { Strongly } \\
\text { disagree }\end{array}$ & Disagree & $\begin{array}{l}\text { Neither } \\
\text { agree } \\
\text { nor } \\
\text { disagree }\end{array}$ & Agree & $\begin{array}{c}\text { Strongly } \\
\text { agree }\end{array}$ & \\
\hline 1 & $\begin{array}{l}\text { The consumers purchase } \\
\text { Cavendish bananas at the } \\
\text { Modern Market in Semarang } \\
\text { because they need and feel that } \\
\text { the product is suitable for them. }\end{array}$ & 0 & 1 & 16 & 53 & 30 & 4.12 \\
\hline 2 & $\begin{array}{l}\text { The consumers purchase } \\
\text { Cavendish bananas at the } \\
\text { Modern Market in Semarang } \\
\text { because they get information } \\
\text { about the product according to the } \\
\text { information that they needed } \\
\text { through the promotions carried } \\
\text { out }\end{array}$ & 3 & 9 & 34 & 40 & 14 & 3.53 \\
\hline 3 & $\begin{array}{l}\text { The consumers purchase } \\
\text { Cavendish bananas at the } \\
\text { Modern Market in Semarang } \\
\text { because they have evaluated and } \\
\text { compared in terms of price and } \\
\text { place }\end{array}$ & 4 & 6 & 22 & 55 & 13 & 3.67 \\
\hline 4 & $\begin{array}{l}\text { The consumers purchase } \\
\text { Cavendish bananas at the } \\
\text { Modern Market in Semarang } \\
\text { because they have made the } \\
\text { decision to purchase by } \\
\text { considering the product, price, } \\
\text { place and promotion }\end{array}$ & 2 & 4 & 13 & 60 & 21 & 3.94 \\
\hline 5 & $\begin{array}{l}\text { The consumers are satisfied with } \\
\text { the product, and they will make a } \\
\text { repeat purchase }\end{array}$ & 1 & 0 & 19 & 57 & 23 & 4.01 \\
\hline & & $\bar{Y}$ & & & & & 3.85 \\
\hline
\end{tabular}

Source: Primary Data Analysis, 2021

Table 7 shows that Cavendish banana products sold at the Modern Market in Semarang are in accordance with consumer desires in terms of appearance, quantity, taste and aroma so that consumers decide to purchase. It is as opinion from Rumapea et al. (2021) stating that consumers in making decisions to purchase banana consider several things, like taste, peel color, size and number of banana per comb. Meanwhile, most of consumers' reason to purchase Cavendish bananas is because the promotions carried out are in accordance with the information needed, while some others claim that the decision to purchase is not because of promotions. Therefore, there needs to increase they way of promotions through media that are currently on hype so that consumers will more easily find out the promotion. Enggal et al. (2019) argues that the way that can be done in promoting a product is to do promotions according to the media that is often used so that consumers can easily find out about the promotion.

Most of the consumers decide to purchase Cavendish bananas after evaluating or comparing Cavendish bananas in terms of price and place in several places. Meanwhile, some others only compare in terms of price, but they do not compare in terms of place or vice versa. It is in line with Kurniawan \& Astuti (2012) stating that in deciding to purchase, price and place are important, in which consumers prefer having products at prices 
matching their income to having products with higher price, and they prefer safer and easier to reach compare to other places.

While most of the respondents decide to purchase Cavendish bananas because they claim it was suitable from all variables namely product, price, place and promotion, while others decide to purchase because they claim it was suitable only from one variable or only from several variables. According to Enggal et al. (2019), the marketing mix in the form of product, price, promotion and place has significant effect on purchase decision. In addition, consumers who are satisfied with the Cavendish bananas they purchased in terms of product, price, place and promotion will decide to repurchase. It is in line with the research conducted by Pupuani \& Sulistyawati (2013) stating that the marketing mix consisting of product, price, place and promotion affect consumer repurchase behavior, where if consumers are satisfied, the opportunity to make repeat purchases will also be higher.

\section{Normality test}

Table 8. Result of normality test

\begin{tabular}{|c|c|c|}
\hline Variable & Asymp. Sig. (2-tailed) & Information \\
\hline Product & 0.093 & Normal \\
\hline Price & 0.103 & Normal \\
\hline Place & 0.088 & Normal \\
\hline Promotion & 0.120 & Normal \\
\hline Purchase Decision & 0.082 & Normal \\
\hline
\end{tabular}

Source: Primary Data Analysis, 2021

Table 8 shows that the data used is normally distributed because it has a significance value of more than $0.05(5 \%)$. It is in accordance with Annisa et al. (2017) stating that the normality test is carried out using the Kolmogorov-Smirnov test. The condition is that if the significant value is $5 \%$ or 0.05 , the data is normal.

\section{Classic assumption test}

The results of the multicollinearity test indicate that the regression model used in this study does not occur multicollinearity because all variables used have a VIF value $<10$ and a tolerance $>0.10$. It is as opinion from Sugiarto et al. (2017) stating that in the multicollinearity test, if the tolerance value is $>0.10$ and VIF $<10$, the data is said to have no multicollinearity.

The value of DW from the results of the autocorrelation test carried out was between the values of $\mathrm{dU}$ and $(4-\mathrm{dU})$ so that in this study there was no autocorrelation, namely $1.758<1.836<2.242$. It is in accordance with Zamroni (2016) stating that there are three criteria in the autocorrelation test. First, if DW lies between $\mathrm{dL}$ and $\mathrm{dU}$ or between ( $4-\mathrm{dU})$ and $(4-\mathrm{dL})$, it cannot be concluded with certainty; second, if DW lies between dU and (4 $\mathrm{dU})$, there is no autocorrelation; and third, if $\mathrm{dW}<\mathrm{dL}$ or $\mathrm{dW}>(4-\mathrm{dL})$, autocorrelation occurs

The results of the heteroscedasticity test show that the points in the scatterplot graph of the heteroscedasticity test do not form a certain pattern and spread to almost all parts of the graph including those above and below 0 , it can be said that there is no heteroscedasticity in the data used in this study. Sugiarto et al. (2017) argues that the heteroscedasticity test can be identified by using the scatterplot graph, if the points on the scatterplots spread and do not form a certain pattern or are above or below the 0 value on the $Y$ axis, the data does not experience heteroscedasticity.

\section{Normality error test}

The results of the normality error test show that the data is spread out following the diagonal line, which is along the line of $45^{\circ}$ and the residual data has an value of Asymp. Sig. (2-tailed) of 0.422 . It shows that the data has a normal distribution. In line with the opinion of llat et al. (2018) stating that if a data is spread around a diagonal line of $45^{\circ}$ on a normal plot graph, the data is normal. It is supported by Ayuningtyas \& Gunawan (2018) stating that if the residual data in a study has a significance value $>0.05$, the residual data has a normal distribution.

\section{Coefficient of determination}

The coefficient of determination test having been carried out shows the Adjusted R Square (R2) value of 0.506 , which means that as much as $50.6 \%$ of the diversity of the dependent variable, namely the decision to purchase Cavendish bananas can be explained by independent variables (price, product, promotion and place) while the rest are $49.4 \%$ is explained by other variables that are not used in this study. The value of the coefficient of determination produced is included in the good category because the value is close to 1 so that it is able to 
explain the dependent variable. It is in accordance with Ghozali (2018) stating that if a data has an R2 value or a coefficient of determination close to 1 , the ability of the independent variable to explain the dependent variable is getting better, and if a data has an R2 value or a coefficient of determination that is small and is getting away from 1 , the ability of the independent variable to explain the variation of the variable dependent is also limited.

\section{Multiple linear regression test}

Based on the Multiple Linear Regression Test having been carried out, the following results are obtained: $Y=1,430+0,299 X_{1}+0,670 X_{2}+0,234 X_{3}+0,284 X_{4}+e$

These equations can be explained, as follow:

1. The constant (a) is 1.430 , which means that if the price, product, promotion and place variables are constant. The decision to purchase Cavendish bananas at the Modern Market in Semarang is 1.430.

2. The product variables (X1), price (X2), place (X3) and promotion (X4) have positive regression coefficient values so that all these variables have a positive relationship to the decision to purchase Cavendish bananas at the Modern Market in Semarang. It is in accordance with Dewi dan Sutanto (2018) stating that in the multiple linear regression test, an independent variable can be said to have a positive relationship to the dependent variable if it has a positive coefficient value.

\begin{tabular}{llrrrrrr}
\hline & Model & Sum of Squares & Df & $\begin{array}{c}\text { Mean } \\
\text { Square }\end{array}$ & $F_{\text {count }}$ & $F_{\text {table }}$ & Sig. \\
\hline 1 & Regression & 532.373 & 4 & 133.093 & 26.378 & 2.47 & $0.000^{\text {a }}$ \\
Residual & 479.337 & 95 & 5.046 & & & \\
$\quad$ Total & 1011.710 & 99 & & & & \\
\hline
\end{tabular}

Source: Primary Data Analysis, 2021

The value of $F_{\text {count }}$ and $F_{\text {table }}$ contained in Table 9 shows that the $\mathrm{H}_{1}$ of this study was accepted and $\mathrm{H}_{0}$ was rejected because the calculated $F$ count $>F_{\text {table }}$ was $26.378>2.47$ and the sig value. $<0,05$ which means that the independent variables used in this study are price, product, promotion and place simultaneously affect the dependent variable, namely purchasing decisions. It is as opinion from Lubis \& Hidayat (2017) stating that the independent variable in a study can be said to have a simultaneous effect on the dependent variable if the calculated $F_{\text {count }}>F_{\text {table }}$ and has a significant value $<0.05$. It is supported by Ghozali (2018) stating that if $\mathrm{H} 0$ is rejected and $\mathrm{H} 1$ is accepted with a significance value $<0.05$, it can be concluded that the independent variables simultaneously affect the dependent variable. According to Pertiwi et al. (2016), marketing mix, product, place, price and promotion, have a joint effect on purchasing decisions, because it is a marketing tool that can be planned according to market desires.

Table 10. Result of t-test

\begin{tabular}{lccc}
\hline \multicolumn{1}{c}{ Variable } & $\mathrm{t}_{\text {count }}$ & $\mathrm{t}_{\text {table }}$ & Sig. \\
\hline Product & 1.999 & 1.984 & 0.048 \\
Price & 5.055 & 1.984 & 0.000 \\
Place & 1.849 & 1.984 & 0.067 \\
Promotion & 3.266 & 1.984 & 0.002 \\
\hline
\end{tabular}

Source: Primary Data Analysis, 2021

Based on the t-test that has been carried out, the calculated $t_{\text {count }}$ on the product variable is 1.999 with a sig value. of 0.048 ; the price variable is 5.055 with a sig value. of 0.000 ; the place variable is 1.849 with a sig value. of 0.067 ; and the promotion variable is 3.266 with a sig value. of 0.002 . This value indicates that $\mathrm{HO}$ is rejected and $\mathrm{H} 1$ is accepted on the product, price and promotion variables because it has a $t_{\text {count }}>t_{\text {table, }}$, which is $1.999>1.984$ and a sig value. of $<0.05$, while $\mathrm{H} 1$ is rejected and $\mathrm{H} 0$ is accepted on the place variable because it has value of $\mathrm{t}_{\text {count }}<\mathrm{t}_{\text {table }}$ which is $1.849>1.984$ and a sig value. of $>0.05$. It means that the variables of price, product and promotion has significant effect on purchase decisions, while the variable of place has no effect on purchase decisions. It is in accordance with research conducted by Kurniawan dan Astuti (2012) stating that the price and place variables have no effect on purchase decisions partially. It is supported by Shandy (2015) stating that in the research conducted, price and promotion variables have a partial effect on purchase decisions, while product, place or location, people, physical evidence and process variables have no effect on purchase decisions.

Selang (2013) states that consumers in making decisions to purchase consider many factors, like product advantages, price advantages and services, so it is evident that the product and price variables in this study affect the decisions to purchase Cavendish bananas in the Modern Market of Semarang. Consumers decide to purchase Cavendish bananas because this banana has advantages over other bananas. According to Shintia 
(2019), Cavendish bananas have a clean yellow peel, soft flesh and not too sweet taste. In addition, it also has good nutritional content for the body, as stated by Setianingsih et al. (2017) stating that Cavendish banana contains crude fiber which is good for the digestive tract and can be consumed in large quantities because it contains relatively little fat, and Cavendish banana also contains protein which is good for the growth process. Amanda (2011) states that the potassium content in Cavendish bananas is about $476 \mathrm{mg}$ which is useful for lowering blood pressure. Most consumers also agree about the price given, which is affordable price. Moreover, the price is in accordance with the quality provided, and there is a discount so that consumers decide to purchase Cavendish bananas at the Modern Market in Semarang. It is in accordance with the opinion from Dewi dan Sutanto (2018) stating that purchase decisions can be affected by prices that match the benefits of a product, affordable prices and prices that match product quality.

Promotion is also carried out through various media, namely through events/exhibitions, advertisements and social media that can make it easier for consumers to obtain information about products, so that it can cause consumers easier to decide whether to make a purchase or not. It is as Sangadji (2019) stating that the more promotions are carried out, the more information consumers will receive so that the more the chances of consumers purchase the product. Cavendish banana is a type of banana that is more often found in modern markets than in other sales places so that consumers consider other factors more than the place like the cleanliness of the place, product availability and product arrangement. Therefore, those other factors can be paid more attention. It in in line with the research by Marendra (2018) stating that the factors requiring to be considered in the selection of sales point are the surrounding environment, competition with competitors similar to the business, the possibility of expansion and road access.

\section{CONCLUSION}

The conclusions that can be drawn from the above discussion are:

1. Descriptive analysis shows that the product variable has a fairly good average; the price variable has an average value that is less good; the place variable is good enough; the promotion variable also has an average value that is less good; and the purchase decision variable has an average value with fairly good average.

2. Statistical analysis shows that the variables of price, product, promotion and place simultaneously affect the purchase decision of Cavendish bananas. Price, product and promotion variables have a partial effect, while the place variable has no effect on purchase decisions for Cavendish bananas at the Modern Market in Semarang.

\section{DAFTAR PUSTAKA}

Amanda, R. T. (2011). Pengaruh Buah Pisang Cavendish (Musa Cavendishi) terhadap Tekanan Darah Normal Laki-Laki Dewasa. Universitas Kristen Maranatha.

Amilia, S. (2017). Pengaruh Citra Merek, Harga, dan Kualitas Produk terhadap Keputusan Pembelian Handphone Merek Xiaomi di Kota Langsa. Manajemen Dan Keuangan, 6(1), 660-669.

Annisa, A. I., Supardi, S., \& Irianto, H. (2017). Analisis Pengaruh Brand Equity terhadap Keputusan Pembelian Sari Buah Dalam Kemasan di Supermarket Kota Surakarta (Kasus pada sari buah dalam kemasan merek Buavita). Agrista, 5(3), 255-267.

Apriando, J. P., Soesanto, H., \& Indriani, F. (2019). Pengaruh Kualitas Produk Dan Ketersediaan Produk Terhadap Keputusan Pembelian Dengan Citra Merek sebagai Variabel Intervening (Studi Pada Konsumen Minuman Energi M-150 Di Kota Semarang). Jurnal Sains Pemasaran Indonesia (Indonesian Journal of Marketing Science), 18(2), 166-183.

Ayuningtyas, K., \& Gunawan, H. (2018). Pengaruh Kepercayaan, Kemudahan dan Kualitas Informasi terhadap Keputusan Pembelian Daring di Aplikasi Bukalapak pada Mahasiswa Politeknik Negeri Batam. Administrasi Bisnis Terapan, 2(1), 152-165.

Badan Pusat Statistik. (2018). Statistik Tanaman Buah-buahan dan Sayuran Tahunan 2018.

Darmawan. (2013). Metode Penelitian Kuantitatif. Remaja Rosdakarya.

Darmawan, D. (2017). Pengaruh Kemasan dan Harga Terhadap Keputusan Pembelian Produk Sayuran Hidroponik. Agrimas, 1(1), 1-10.

Dewi, O. I., \& Sutanto, E. M. (2018). Pengaruh Bauran Pemasaran terhadap Keputusan Pembelian Konsumen 
Chang Tea Di Surabaya. Agora, 6(2), 1-6.

Eliza, Sayamar, E., \& Kaswita, C. (2011). Analisis Faktor-Faktor yang Mempengaruhi Konsumen dalam Pengambilan Keputusan Pembelian Buah di Pasar Arengka (Pasar Tradisional) dan Giant Hypermarket (Pasar Modern) di kecamatan Tampan Kota Pekanbaru. Indonesian Journal of Agricultural Economics (IJAE), 2(1), 15-34.

Enggal, T. W., Bukhori, M., \& Sudaryanti, D. (2019). Analisa Bauran Pemasaran yang Mempengaruhi Keputusan Pembelian Baju di Beberapa Departement Store di Kota Malang. Jurnal Ilmiah Bisnis Dan Ekonomi Asia, 13(2), 61-70.

Ghozali, I. (2018). Aplikasi Analisis Multivariate dengan Program IBM SPSS 25 (9th ed.). Badan Penerbit Universitas Diponegoro.

Hanifaradiz, A., \& Satrio, B. (2016). Pengaruh Bauran Pemasaran terhadap Keputusan Pembelian Sabun Mandi Lifebuoy di Surabaya. IImu Riset Dan Manajemen, 5(6), 1-17.

Indriyanti, I. Y., Irianto, H., \& Sundari, M. T. (2019). Analisis Faktor Bauran Pemasaran terhadap Keputusan Pembelian Minuman Kopi Banaran 9 di Coffee and Tea Colomadu. Agriecobis : Journal of Agricultural Socioeconomics and Business, 2(1), 47-57.

Jamaluddin, M. A., Widodo, W. D., \& Suketi, K. (2019). Pengelolaan Perkebunan Pisang Cavendish Komersial di Lampung Tengah, Lampung. Buletin Agrohorti, 7(1), 16-24.

Kurniawan, A. D., \& Astuti, S. R. T. (2012). Analisi Pengaruh Produk, Promosi, Harga dan Tempat Terhadap Keputusan Pembelian (Studi Pada Kedai Amarta Semarang). Manajemen, 1(1), 282-289.

Lubis, D. I. D., \& Hidayat, R. (2017). Pengaruh Citra Merek dan Harga terhadap Keputusan Pembelian pada Sekolah Tinggi IImu Manajemen Sukma Medan. IImu Manajemen, 5(1), 15-24.

Manik, S., \& Rianti, B. (2019). Pengaruh Bauran Pemasaran terhadap Keputusan Pembelian Es Krim Sayur Broco Es Krim di Pekanbaru. Jurnal Manajemen Dan Bisnis, 8(1), 162-175.

Marendra, I. G. (2018). Pengaruh Bauran Pemasaran (Produk, Harga, Lokasi Dan Promosi) terhadap Keputusan Pembelian Konsumen di Minimarket (Alfamart Atau Indomaret). 1(3), 34-52.

Murod, N., Rochaeni, S., \& Ichdayati, L. I. (2018). Pengaruh Kesadaran, Persepsi dan Preferensi Konsumen Terhadap Perilaku Konsumen dalam Mengkonsumsi Buah Lokal di Kawasan Perpasaran Jakarta Barat. Agribusiness Journal, 12(2), 86-96.

Octaviani, M. F., Indriani, Y., \& Situmorang, S. (2017). Pengaruh Bauran Pemasaran (Marketing Mix) dan Perilaku Konsumen Terhadap Pengambilan Keputusan Pembelian Jus Buah Segar Bandar Lampung. Agribisnis Dan Agrowisata, 6(4), 584-595.

Padmi, N. M. S. K. D., Dewi, R. K., \& Aggraeni, I. G. A. A. L. (2017). Analisis Perilaku Konsumen terhadap Keputusan Pembelian Buah-Buahan di Moena Fresh Bali. Jurnal Agribisnis Dan Agrowisata (Journal of Agribusiness and Agritourism), 6(4), 584-595.

Pertiwi, M. I., Yulianto, E., \& Sunarti. (2016). Pengaruh bauran pemasaran terhadap keputusan pembelian (Survei pada konsumen Baker's King Donuts \& Coffee di MX Mall Malang). Administrasi Bisnis, 37(1), 179-186.

Prasastiningtyas, T. R., \& Djawoto. (2016). Pengaruh Citra Merek, Kualitas Produk, dan Harga terhadap Keputusan Pembelian Kartu Seluler. IImu Riset Dan Manajemen, 5(7), 1-15.

Pupuani, N., \& Sulistyawati, E. (2013). Pengaruh Bauran Pemasaran Terhadap Kepuasan Konsumen dan Perilaku Pembelian Ulang (Studi Kasus Pada Produk Pasta Gigi Merek Pepsodent di Kota Denpasar). EJurnal Manajemen Universitas Udayana, 2(6), 683-702.

Rakasyifa, I., \& Mukti, G. W. (2020). Faktor-Faktor yang Mempengaruhi Keputusan Pembelian Sayur dan Buah di Ritel Online (Suatu Kasus pada konsumen Ritel Online di Jakarta). Mimbar Agribisnis: Jurnal Pemikiran Masyarakat Ilmiah Berwawasan Agribisnis, 6(1), 275-289.

Rumapea, E., Roessali, W., \& prasetyo, edy. (2021). Analisis Sikap dan Preferensi Konsumen terhadap Keputusan Pembelian Buah Pisang di Pasar Tradisional Kota Semarang. Agrisocionomics, 05(02), 1-13.

Sangadji, S. (2019). Pengaruh Bauran Pemasaran terhadap Keputusan Pembelian Sagu Rasa pada Gabungan Kelompok Tani Tagafura di Kelurahan Jaya Kota Tidore Kepulauan. Jurnal Ekonomi Dan Kewirausahaan: OPTIMAL, 13(2), 142-157.

Selang, C. A. D. (2013). Bauran Pemasaran (Marketing Mix) Pengaruhnya terhadap Loyalitas Konsumen pada 
Freshmart Batu Mall Manado. Riset Ekonomi, Manajemen, Bisnis Dan Akuntansi, 1(3), 71-80.

Sesunan, T. M., Yaktiworo, I., \& Listiana, I. (2015). Bauran Pemasaran dan Perilaku Konsumen dalam Pengambilan Keputusan Pembelian Cappuccino Cincau. IImu-IImu Agribisnis, 3(1), 94-99.

Setianingsih, N., Nahdiyah, N., \& Purnamasari, R. (2017). Pengaruh Ekstrak Buah Pisang dan Ekstrak Buah Alpukat Terhadap Kadar Kolesterol Mencit Betina. Biota, 3(2), 48-53.

Shandy, I. A. (2015). Pengaruh Marketing Mix terhadap Keputusan Pembelian Konsumen pada Minimarket Lulumart di Kota Samarinda. IImu Administrasi Bisnis, 3(1), 174-188.

Shinta, A. (2011). Manajemen Pemasaran. UB Press.

Shintia, B. (2019). Analisis Keputusan Konsumen terhadap Pembelian Pisang Cavendish (Musa Cavendishii) di Brastagi Supermarket Medan (Skripsi). Fakultas Pertanian Universitas Muhammadiyah Sumatera Utara.

Sugiarto, M. E., Kumaat, R. M., \& Pakasi, C. B. D. (2017). Faktor-faktor yang Mempengaruhi Konsumen dalam Keputusan Pembelian Buah di Freshmart Tikala Kota Manado. J. Agri-SosioEkonomi Unsrat. AgriSosioekonomi, 13(1A), 17-32.

Sugiono. (2015). Metode Penelitian Kuantitatif, Kualitatif dan R \& D. Alfabeta.

Sundalangi, M., Mandey, S. L., \& Jorie, R. J. (2014). Kualitas Produk, Daya Tarik Iklan, dan Potongan Harga Terhadap Minat Beli Konsumen pada Pizza Hut Manado. Jurnal Riset Ekonomi, Manajemen, Bisnis Dan Akuntansi, 2(1), 313-324.

Sungkawa, I., Purnomo, D., \& Fauziah, E. (2015). Pengaruh Bauran Pemasaran terhadap Kepuasan Konsumen dan Perilaku Pembelian Ulang (Studi Kasus Pada Produk Pasta Gigi Merek Pepsodent di Kota Denpasar). Agrijati, 28(1), 79-99.

Suyanti, \& Supriyadi, A. (2008). Pisang, Budidaya, Pengolahan dan Prospek Pasar. Penebar Sadaya.

Weenas, J. (2013). Kualitas Produk, Harga, Promosi dan Kualitas Pelayanan Pengaruhnya terhadap Keputusan Pembelian Spring Bed Comforta. Jurnal Riset Ekonomi, Manajemen, Bisnis Dan Akuntansi, 1(4), 607618.

Winawan, B., \& Yasa, N. N. K. (2014). Pengaruh Penataan Produk, Jenis Kelamin, dan Taraf Belanja Terhadap Keputusan Pembelian Tidak Terencana (Studi Kasus pada Konsumen Ritel di Kota Denpasar). Manajemen, 3(7), 2133-2149.

Yusuf, A. M. (2017). Metode Penelitian : Kuantitatif, Kualitatif dan Penelitian Gabungan (4th ed.). Kencana.

Zamroni, A. (2016). Pengaruh Citra Merek, Kualitas Produk dan Promosi Terhadap Keputusan Pembelian Produk Pepsodent pada Konsumen Indomaret Plus di Jalan M. Yamin Samarinda. Administrasi Bisnis, 4(4), 960-974. 